\title{
IMPACT OF DEMONETIZATION ON STOCK MARKET OF INDIA
}

\author{
Deepika Chaurasia \\ 46, Park Road, Dehradun \\ Contact number: 09997440710, email id: deepsacharya20@ gmail.com
}

\section{ABSTRACT}

Demonetization can be describes as a process where the use of a particular existing currency is banned from a particular date and time, and a new currency may or may not be introduced in place of it. There are a number of countries who have adopted demonetisation in history to tackle various issues like black money, terrorism or illegal activities. India is amongst one of them. Other than India countries like Nigeria in 1984, Ghana in 1982, Pakistan in 2016, Zimbabwe, North Korea in 2010, Australia and Myanmar in 1987 have used demonetization before, though in some countries it had a positive effect whereas some countries are facing its adverse effect till today.

Now if we talk about stock market also known as stock exchange it is a place where the buyers and sellers perform economic transactions of shares, debentures, securities. In order to measure the performance of stock market an index is used. An index is a statistical measure of change in an economy or a security market it comprises of set of securities which are combined on the basis of some similarity, so that they can represent a market or a part of market. A stock market index (or just "index) is a number that measures the relative value of a group of stocks. As the stocks in this group change their value, the index also changes its value.

Key words: Demonetization, currency, stock market, shares, debentures, securities, index, stock.

\section{INTRODUCTION}

\section{Demonetization in Indian context:}

Recently, India witnessed demonetization on 8, November 2016, midnight, when government declared ban on use of banknotes of 500 and 1000 of mahatma Gandhi series in order to control black money, terrorism and illegal activities prevailing in economy. New banknotes of Rs. 500 and 2000 were introduced. Demonetization leads to 86 per cent of all currency out of circulation. But this was not the first time when India applied demonetization on the nation, if we look towards the history the first case of demonetization in India was recorded in 1946 i.e. just after India got independence, here main motive behind demonetization was cutting down the profits gained by those businessmen who have gained them by associating with the allies of world war II , the second case of demonetisation was recorded in 1978, by janta party where banknotes of 1000,5000 and 10,000 were demonetized in order to control black money in economy.

\section{Stock market of India:}

The stock market of India is comprised of BSE and NSE which stands for Bombay stock exchange and national stock exchange respectively. Indian stock market started with the birth of Bombay stock exchange in 1875.BSE is Asia's first and world's fastest stock exchange with a median trade speed of 6 microseconds. There are about 5000 listed companies on the BSE while NSE comprised of about 1600 listed companies only. That is why in this research an index of BSE i.e. SENSEX is considered as it is the base for Indian stock market.

\section{Objectives of study:}

1. To understand demonetization in India.

2. To understand relation between demonetization and stock market.

3. To analyze the impact of demonetization on stock market of India. 
Table 1: monthly opening, closing, high and low values for the financial year 2016-17:

\begin{tabular}{|c|c|c|c|c|c|}
\hline MONTH & OPEN & HIGH & LOW & CLOSE & RISE/FALL \\
\hline March-16 & $23,153.32$ & $25,479.62$ & $23,133.18$ & $25,341.86$ & \\
\hline April -16 & $25,301.70$ & $26,100.54$ & $24,523.20$ & $25,606.62$ & 264.76 \\
\hline May -16 & $25,565.44$ & $26,837.20$ & $25,057.93$ & $26,667.96$ & $1,061.34$ \\
\hline June -16 & $26,684.46$ & $27,105.41$ & $25,911.33$ & $26,999.72$ & 331.76 \\
\hline July -16 & $27,064.33$ & $28,240.20$ & $27,034.14$ & $28,051.86$ & $1,052.14$ \\
\hline August -16 & $28,083.08$ & $28,532.25$ & $27,627.97$ & $28,452.17$ & 400.31 \\
\hline September -16 & $28,459.09$ & $29,077.28$ & $27,716.78$ & $27,865.96$ & -586.21 \\
\hline October -16 & $27,997.29$ & $28,477.65$ & $27,488.30$ & $27,930.21$ & 64.25 \\
\hline November -16 & $27,966.18$ & $28,029.80$ & $25,717.93$ & $26,652.81$ & $-1,277.40$ \\
\hline December -16 & $26,756.66$ & $26,803.76$ & $25,753.74$ & $26,626.46$ & -26.35 \\
\hline January -17 & $26,711.15$ & $27,980.39$ & $26,447.06$ & $27,655.96$ & $1,029.50$ \\
\hline February -17 & $27,669.08$ & $29,065.31$ & $27,590.10$ & $28,743.32$ & $1,087.36$ \\
\hline March -17 & $28,849.04$ & $29,824.62$ & $28,716.21$ & $29,620.50$ & 877.18 \\
\hline
\end{tabular}

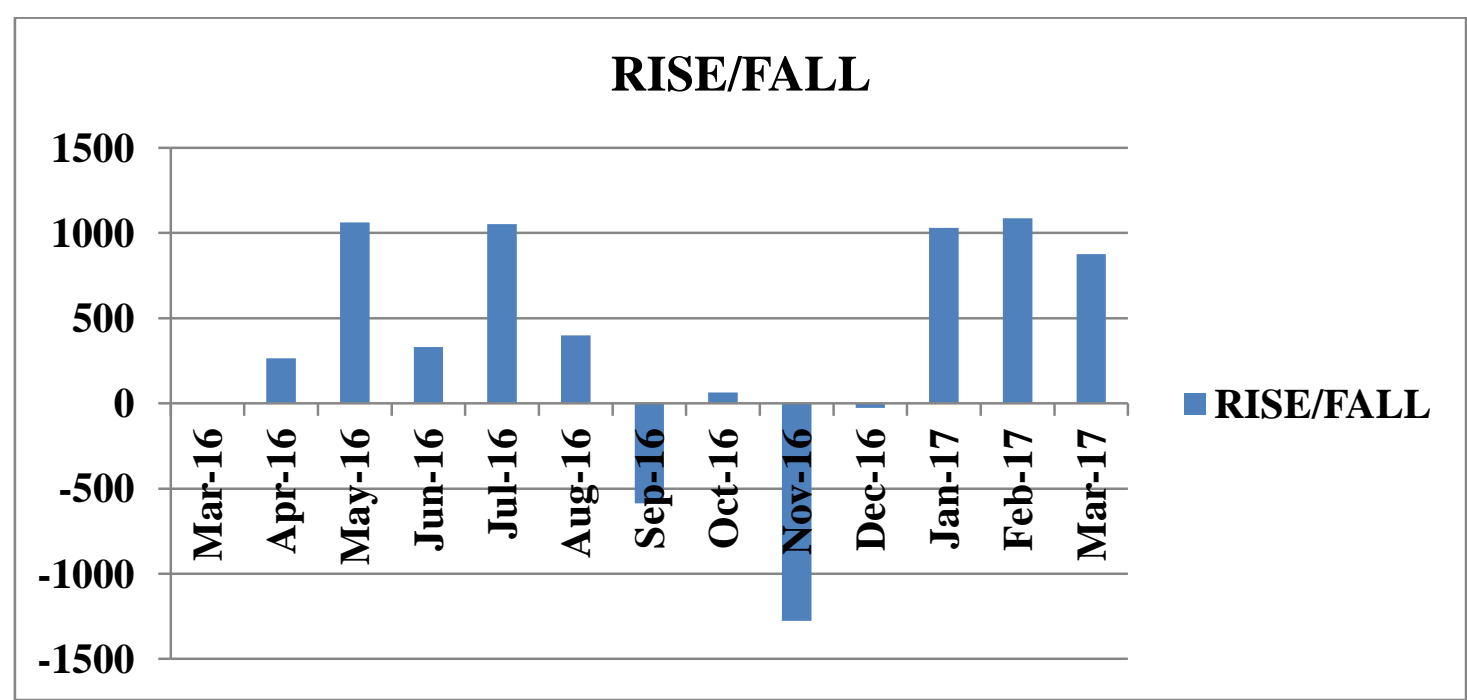

\section{Figure 1}

\section{Interpretation:}

Table 1 represents the monthly opening, closing, high and low values of the sensex for the year 2016-17, which are represented through column chart in figure 1.

Table 1 is further divided into two categories which are:

a) Before demonetization

b) After demonetization

Before demonetization includes months from April 2016 to October 2016, this will be our first sample for study, represented by table 2 .

After demonetization includes November 2016 to march 2017, this will be our second sample for study, represented by table 3 . 
Table 2: Monthly Opening and Closing Values of BSE Sensex of Year 2016-17 from March 2016 to

October 2016:

\begin{tabular}{|l|r|r|r|}
\hline \multicolumn{1}{|c|}{ MONTH } & OPEN & \multicolumn{1}{c|}{ CLOSE } & RISE / FALL (X) \\
\hline Mar-16 & $23,153.32$ & $25,341.86$ & 264.76 \\
\hline Apr-16 & $25,301.70$ & $25,606.62$ & $1,061.34$ \\
\hline May-16 & $25,565.44$ & $26,667.96$ & 331.76 \\
\hline Jun-16 & $26,684.46$ & $26,999.72$ & $1,052.14$ \\
\hline Jul-16 & $27,064.33$ & $28,051.86$ & 400.31 \\
\hline Aug-16 & $28,083.08$ & $28,452.17$ & -586.21 \\
\hline Sep-16 & $28,459.09$ & $27,865.96$ & 64.25 \\
\hline Oct-16 & $27,997.29$ & $27,930.21$ & \\
\hline
\end{tabular}

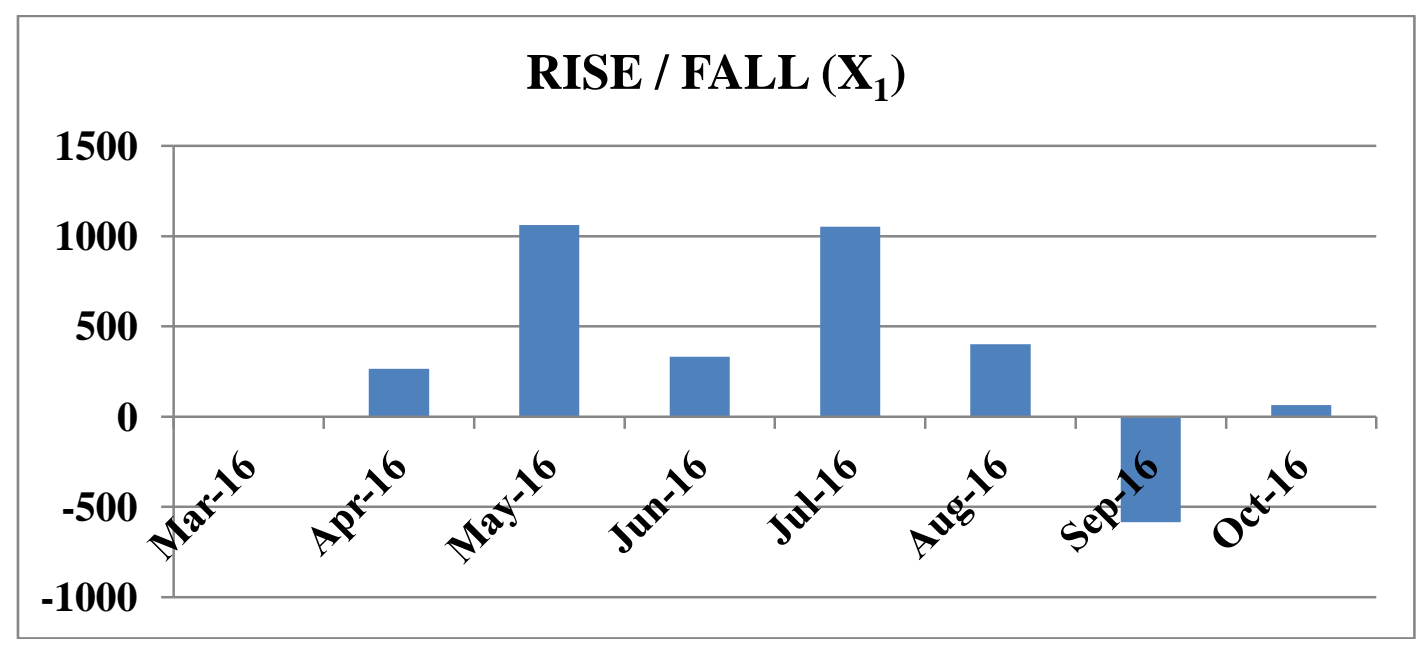

Figure 2

\section{Interpretation:}

Table 2 represents the opening and closing values of BSE SENSEX from March 2016 to October 2016. By using closing values of the previous and current month, rise/fall values are calculated for each month respectively. The rise and fall values are represented graphically in figure 2.

Table 3: Opening and Closing values of BSE sensex of year 2016-17 from November 2016 to March 2017

\begin{tabular}{|c|c|c|c|}
\hline Month & OPEN & CLOSE & Rise /Fall $\left(X_{2}\right)$ \\
\hline Nov-16 & $27,966.18$ & $26,652.81$ & $-1,277.40$ \\
\hline Dec-16 & $26,756.66$ & $26,626.46$ & -26.35 \\
\hline Jan-17 & $26,711.15$ & $27,655.96$ & $1,029.50$ \\
\hline Feb-17 & $27,669.08$ & $28,743.32$ & $1,087.36$ \\
\hline Mar-17 & $28,849.04$ & $29,620.50$ & 877.18 \\
\hline
\end{tabular}




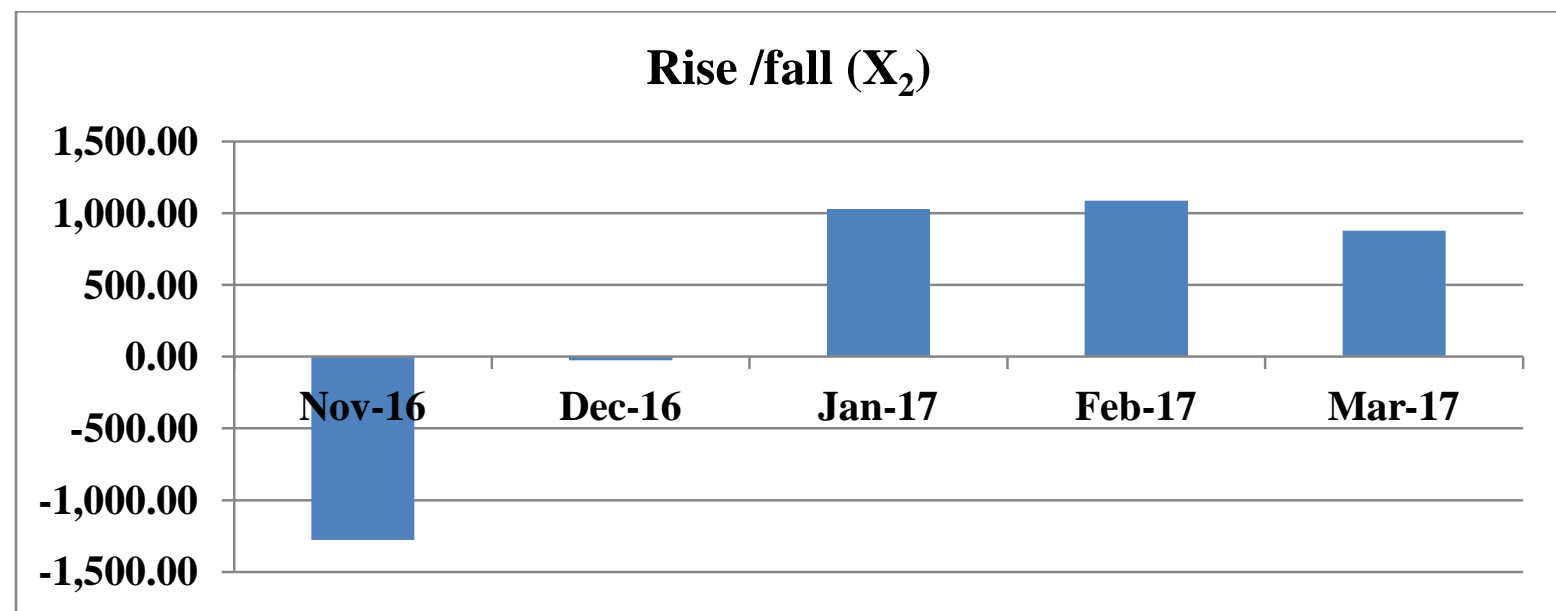

Figure 3

\section{Interpretation:}

Table 3 represents the monthly opening and closing values of BSE SENSEX from November 2016 to March 2017. By using closing values of previous and current month rise/fall values are calculated for each month respectively. Month wise rise and fall of sensex is represented using column chart in figure 3.

\section{MATERIALS AND METHODS}

Table 4: T TEST RESULTS:

\begin{tabular}{|l|l|l|l|l|}
\hline \multicolumn{1}{|c|}{$\mathbf{n}$} & \multicolumn{1}{|c|}{ MEAN } & $\begin{array}{c}\text { STANDARD } \\
\text { DEVIATION }\end{array}$ & $\begin{array}{c}\text { T TEST } \\
\text { RESULTS }\end{array}$ & \multicolumn{1}{c|}{ P VALUE } \\
\hline 7 & 369.7642857 & \multirow{2}{*}{776.9966835} & $\mathbf{0 . 0 6 9}$ & $\mathbf{0 . 9 4 6 3}$ \\
\hline 5 & 338.058 & & & \\
\hline
\end{tabular}

\section{Interpretation:}

Table 3 represents the mean, standard deviation, $\mathrm{T}$ test result and $\mathrm{p}$ value. Mean and standard deviation is calculated using rise and fall values of table 2 and table 3, and t test results are calculated using mean and standard deviation.

\section{IMPACT OF DEMONNITIZATION ON INDIAN STOCK MARKET}

In order to analyse the impact of demonetization on Indian stock market, the opening and closing values of BSE SENSEX are taken into consideration for the year 2016-17 as this was the financial year during which demonetization was applied to control and coordinate the economy of India. Demonetization was applied on the midnight of 8 November 2016, so we are dividing the financial year 2016-17 into group of data.

Here, Table 2 represents the first group of data which is from April 2016 to October 2016. This represents data before demonetization.

Table 3 represents the second group of data which is from November 2016 to March 2017. This represents data after demonetization.

In table 2 and table 3 the rise/fall values of sensex for the respective months are calculated using below mentioned formula:

Rise/fall value $=$ recent closing value - previous closing value

If results are positive then there is a rise and if the results are negative then there is a fall. 
In order to find out the impact of demonetization on Indian stock market $\mathbf{t}$ test is applied to the collected data and two hypothesis were formed

Ho: demonetization influenced sensex to fall.

Ha: demonetization influenced sensex to rise.

To test the above mention hypothesis table 4 is used which provide us with mean, standard deviation and $\mathrm{t}$ test results.

Mean: mean is the sum of the data divisible by total number of data. Mean is denoted by ' $\mathbf{X}$ '. Formula for mean is

$\operatorname{Mean}(\overline{\mathrm{X}})=\sum \boldsymbol{f} / \boldsymbol{n}$

Here we have two group of data i.e. two samples, for first sample mean is $\mathbf{3 6 9 . 7 6 4 2 8 5 7}$ and for second sample mean is $\mathbf{3 3 8 . 0 5 8}$

Standard Deviation: Standard Deviation is denoted by ' $S$ ' and calculated using following formula:

$S=\sqrt{\frac{\sum\left(X_{1}-\bar{X}_{1}{ }^{2}+\sum\left(X_{2}-\bar{X}_{2}\right)^{2}\right.}{\left(n_{1}+n_{2}-2\right)}}$

Standard deviation is applied to both the samples which came out equals to $\mathbf{7 7 6 . 9 9 6 6 8 3 5}$

T test: $t$ test or better known as student's $t$ test was applied using mean and standard deviation in order to test the above mentioned hypothesis. Here t test was used as sample size was below 30 and test for unequal sample was used as the size of the two samples (n) which we have considered to study was not equal, the first sample is comprised of 7 months i.e. from April 2016 to October 2016 and second sample comprised of 5 months i.e. from November 2016 to March 2017. T test is denoted using ' $t$ '.

Formula used to calculate $t$ test:

$$
t=\frac{\overline{X_{1}}-\overline{X_{2}}}{S} \sqrt{\frac{n_{1} n_{2}}{n_{1}+n_{2}}}
$$

When $\mathbf{t}$ test is applied the result turned out to be 0.069

Now if we compare the $t$ test value to the $p$ value, the $t$ test value / calculated value are less than the $p$ value/ tabulated value.

$0.069<0.9463$

Hence, Null Hypothesis (Ho) Is Accepted.

This means, Demonetization Influenced Sensex to fall.

It is clear from the above test that demonetization leads to fall of sensex, but up to what extend? So in order to answer it we have to analyse data by going through every month. We have considered the opening and closing values of financial year 2016-17. Using these opening and closing values we have calculated the rise and fall values of sensex.

Let's begin with the first month of financial year 2016-17:

APRIL 2016: this is the first month of the financial year 2016, the beginning of the year; this month begins with opening value of 25301.70 and closes with the value of $25,606.62$. This gave sensex a hike of 264.76 points.

MAY 2016: Month begins with the opening value of 25,565.44 and closed on the value of 26,667.96 and made sensex to rise by $1,061.34$ points.

JUNE 2016: beginning was made with the value of $26,684.46$ and ended on $26,999.72$ which gave a jump to sensex of 331.76 points.

JULY 2016: Here beginning was made with the value of $27,064.33$ and month ending was marked on $28,051.86$. This leads to a rise of sensex by $1,052.14$ points. 
AUGUST 2016: Month started with the value of $28,083.08$ and towards end reached to $28,452.17$. This leads to the rise of sensex by 400.31 points.

SEPTEMBER 2016: This month marked its beginning with the value of $28,459.09$ and ended with 27,865.96, which leads to the fall of sensex by 586.21 points. This was the first time the sensex came down in this year.

OCTOBER 2016: After facing a slight fall in the previous month sensex again moved up by 64 points this month with opening and closing values of 27,997.29 and 27,930.21 respectively.

NOVEMBER 2016: This is the month on which base of our study lies. In this month government of India improvised demonetization to the nation which leads to a major fall of the sensex by $1,277.40$ points, this was the major fall of the financial year 2016-17. The month begins with the value of $27,966.18$ which was a good start but as demonetization was improvised from the midnight of $8^{\text {th }}$ of this month a sudden fall was recorded and this dragged the closing value of the month to 26,652.81.

DECEMBER 2016: In this month again the impact of demonetization can be clearly seen as the value of sensex fallen down by 26 points. The beginning of the month was indicating towards the rise with opening value of 26,756.66 but as the month ended it showed a fall with closing value of 26,626.46.

JANUARY 2016: AFTER witnessing a major fall, January came up with the ray of light, January begins with the value of $26,711.15$ and closed at $27,655.96$, here a rise of $1,029.50$ points was noted in the value of sensex for this month.

FEBRUARY 2016: February gave a good start with the value of 27,669.08 and rested at 28,743.32 towards the end of the month which moved the index up by $1,087.36$ points. Now index was much higher than the value before improvisation of demonetization. It was clear that sensex has now recovered from the effect of demonetization and was looking forward to reach new heights.

MARCH 2016: here beginning was marked with $28,849.04$ and month ended at 29,620.50. In this month sensex moved up by 877.18 points.

If we observe the overall value for the financial year 2016-17, no affect of demonetization can be seen as towards the ends of the year sensex recovered from the effect of demonetization and the closing value of this year was higher than the closing value of the previous year. closing value of sensex for financial year 2015-16 was 25,341.86 and closing value of financial year 2016-17 was 29,620.50, so no affect of demonetization can be observed if we make comparison on the basis of years, but if we analyse the year 2016-17 by going through every month then during the month of November and December the impact can be seen. The fall or rise in the value of sensex is directly proportional to the demand of stocks and securities in the stock market, increase in demand will lead to rise in the value of sensex and decrease in demand will lead to fall of sensex. So as we can clearly see that there was a fall in the value of sensex during the months November and December so this indicates that during November and December the demand of the stock or securities was low, demonetization can be a reason behind it because at that time people were busy arranging or exchanging old currency banknotes with the new one, because of which they paid no attention to the stock market, on the other hand companies whose stocks and securities are bought and sold in the market was also busy in managing and exchanging old banknotes with the new ones so they too paid no attention to the stock of their companies as a result prices fall down, demand fall down, and hence stock market crashed and sensex fall down. There can be lots of other factors too which may lead to the fall of index other than demonetization likewise if we observe the value of the month September 2016 a fall is noted in the value of sensex by 586 points this was clearly not the impact of demonetization as during September demonetization was not applied by the government, it can be due to other factors that affect the index during that phase of time.

\section{CONCLUSION}

DEMONETIZATION impacted economy as well as stock market. The effects are seen negative if we consider it for short run but if talk about the long run demonetization will definitely benefit nation as it will help our nation to fight with the problems like black money and terrorism. Whenever anything new is introduced people takes time to accept it, likewise is our economy and market, it takes time to accept the change but once the change is accepted it grows with a boom. 
The impact of demonetization on Indian stock market by considering the values of BSE SENSEX, $t$ test results, null hypothesis was accepted as per results which shows that demonetization influenced sensex to fall, after analysing the collected opening and closing values of sensex it was observed that there was definitely a fall during the month of November when the improvisation of demonetization was announced lead to the drop of sensex to its five month before closing value. This trend was continued by the month of December when again sensex fallen down but the trend changed with the month of January when the values started to increase, during February sensex overcame the effect of demonetization and by the end of march and the financial year 2016-17 sensex was increasing and reaching to its new heights.

So it can be concluded that demonetization impacted Indian stock market to fall but soon market overcame the effect and reached to its new heights.

\section{REFRENCES}

1. Samy Dr P. Chella and Murugan Bala: "a study on Capital stock market movement in India".

2. https://www.bseindia.com/indices/indexarchivedata.aspx

3. http://www.ways2capital.com/wcblog/effect-of-demonetization-on-indian-stock-market/

4. https://en.wikipedia.org/wiki/2016_Indian_banknote_demonetisation

5. https://www.investopedia.com/terms/d/demonetization.asp

6. https://www.bankbazaar.com/savings-account/demonetisation.html

7. www.economictimes.com

8. www.indiatines.com

9. www.sebi.gov.in

10. Economic political weekly ICFAI Journals

11. Magazines and newspapers: Economic times, Times of India. 